\title{
Relationships between Microsclerotia Content and Hyperspectral Reflectance Data in Soybean Tissue Infected by Macrophomina phaseolina
}

\author{
Reginald S. Fletcher ${ }^{1}$, James R. Smith², Alemu Mengistuㅜㄹ, Jeffery D. Ray ${ }^{2}$ \\ ${ }^{1}$ Crop Production Systems Research Unit, Agricultural Research Service, United States Department of \\ Agriculture, Stoneville, USA \\ ${ }^{2}$ Crop Genetics Research Unit, Agricultural Research Service, United States Department of Agriculture, \\ Stoneville, USA \\ ${ }^{3}$ Crop Genetics Research Unit, Agricultural Research Service, United States Department of Agriculture, \\ Jackson, USA \\ Email: reginald.fletcher@ars.usda.gov
}

Received 28 October 2014; revised 27 November 2014; accepted 9 December 2014

Copyright (C) 2014 by authors and Scientific Research Publishing Inc.

This work is licensed under the Creative Commons Attribution International License (CC BY).

http://creativecommons.org/licenses/by/4.0/

(c) (i) Open Access

\begin{abstract}
Alternative methods are needed to assess the severity of charcoal rot disease [Macrophomina phaseolina (Tassi) Goid] in soybean [Glycine max (L.)] plant tissue. The objective of this study was to define the relationship between light reflectance properties and microsclerotia content of soybean stem and root tissue. Understanding that relationship could lead to using spectral reflectance data as a tool to assess the severity of charcoal rot disease in soybean plants, thus reducing human bias associated with qualitative analysis of soybean plant tissue and cost and time issues connected with quantitative analysis. Hyperspectral reflectance measurements (400 - $2490 \mathrm{~nm}$ ) were obtained with a non-imaging spectroradiometer of non-diseased and charcoal rot diseased ground stem and root tissue samples of six soybean genotypes ("Clark", "LD00-3309", "LG034561-14", "LG03-4561-19", "Saline", and "Y227-1"). Relationships between the reflectance measurements and tissue microsclerotia content were evaluated with Spearman correlation $\left(r_{s}\right)$ analysis $(p<0.05)$. Moderate $\left(r_{s}= \pm 0.40\right.$ to \pm 0.59$)$, strong $\left(r_{s}= \pm 0.60\right.$ to \pm 0.79$)$, and very strong $\left(r_{s}= \pm 0.80\right.$ to \pm 1.00$)$ negative and positive statistically significant $(p<0.05)$ monotonic relationships were observed between tissue spectral reflectance values and tissue microsclerotia content. Nearinfrared and shortwave-infrared wavelengths had the best relationships with microsclerotia content in the ground tissue samples, with consistent results obtained with near-infrared wavelengths in that decreases in near-infrared spectral reflectance values were associated with increases in microsclerotia content in the stem and root tissue of the soybean plants. The findings of
\end{abstract}


this study provided evidence that relationships exist between tissue spectral reflectance and tissue microsclerotia content of soybean plants, supporting spectral reflectance data as a means for assessing variation of microsclerotia content in soybean plants. Future research should focus on the modelling capabilities of the selected wavelengths and on the feasibility of using these wavelengths in machine learning algorithms to differentiate non-diseased from charcoal rot diseased tissue.

\section{Keywords}

Hyperspectral, Stem-Root Tissue, Charcoal Rot, Macrophomina phaseolina, Soybeans

\section{Introduction}

Soybeans [Glycine max (L.)] are an important crop throughout the United States and the world. Charcoal rot disease, caused by the fungus Macrophomina phaseolina (Tassi) Goid, ranked second to sixth among diseases suppressing soybean yield in the United States from 1996 to 2007 [1]. Infected soybean plants develop black specks within the lower plant stem and reddish-brown to black streaks in the vascular tissue of the stems [2] [3]. Leaves turn yellow, wilt, and die [2] [3], and dead leaves remain attached to the soybean plant.

Qualitative and quantitative methods are used to detect charcoal rot disease and the severity of the infection in soybeans plants. Qualitative analysis involves an observer splitting the lower stem and root in half with a knife and then grading is made visually on a rating of 1 to 5 scale where 1 is resistant (no black specks) and 5 is very susceptible (high number of black specks) [4] [5]. Infected tissue has a grayish black color resembling a sprinkling of finely powdered charcoal, hence the name charcoal rot. The grayish black color is caused by the microsclerotia (hardened fungal survival bodies) content in the plant tissue. Even though visual ratings are used for many diseases including charcoal rot, they do not provide quantitative severity data. The use of a quantitative method to enumerate the colony forming unit (CFU) of M. phaseolina [4] [6]-[9] is expensive and time consuming. Alternative methods are needed to assess the severity of charcoal rot disease in soybean plant tissue.

Hyperspectral sensors are becoming invaluable tools for assessing plant stresses, even those caused by fungal and bacteria diseases [10]-[15]. These sensors obtain continuous narrowband light reflectance data encompassing several regions of the light spectrum, affording researchers the opportunity to discriminate diseased tissue from non-diseased tissue and to identify regions of the light spectrum best suited for detecting plant diseases [10] [16].

Disease detection studies with hyperspectral sensors have primarily focused on symptoms occurring in leaf tissues. Charcoal rot injures plants' lower stem and root tissues. Leaf symptoms appear after damage to the stem and roots has occurred. The best diagnostic of charcoal rot disease symptoms is analysis of stem and root tissues of soybeans. No information is available on the relationship between spectral reflectance of soybean stem and root tissues and the microsclerotia content therein. Understanding that relationship could lead to using spectral reflectance data as a tool to assess the severity of charcoal rot disease in soybean plants, thus reducing human bias associated with qualitative analysis of soybean plant tissue and cost and time issues connected with quantitative analysis. Currently, no soybean varieties are immune to charcoal rot disease, although some moderately resistant lines have been released [7]. Spectral reflectance measurements could play a role in helping researchers to make further progress in screening soybean varieties for resistance to charcoal rot and to improve selection in breeding programs. Identifying the relationship between stem and root tissue spectral reflectance data and microsclerotia content is the first step to achieve this goal. The objective of this study was to define the relationship between light reflectance properties and microsclerotia content of soybean stem and root tissue.

\section{Materials and Methods}

\subsection{Plant Sampling}

The ground stem and root tissue analyzed in this study were provided by the coauthors from their ongoing studies. A brief description of the experimental design and tissue sample collection and preparation are described below. 
Six soybean genotypes were grown on a Sharkey clay soil (very-fine, smectic, thermic Chromic Epiaquert) in a field near Stoneville, MS. Planting dates were 13 April 2012 and 29 April 2013. Plants were grown in four-row plots with a row spacing of $96.52 \mathrm{~cm}$ and a row length of $5.8 \mathrm{~m}$. The experimental design was a randomized complete block design with ten replications. The six genotypes consisted of cultivar Clark [17], cultivar Saline [18], cultivar LD00-3309 [19], and three unreleased breeding lines (LG03-4561-14, LG03-4561-19, and Y227-1). All genotypes were maturity group III or IV and had an indeterminate growth habit. Saline was previously shown to be susceptible to charcoal rot [4]. Y227-1 was derived from moderately resistant DT97-4290 [7] and had a similar reaction to charcoal rot as did DT97-4290 (unpublished data of the authors).

As described in detail elsewhere [4] [20] the M. phaseolina isolate used for inoculation was designated "TN4" and was originally recovered from a soybean field in Jackson, Tennessee. TN4 is an aggressive isolate and is maintained as a pure culture. Each year inoculum of $M$. phaseolina was produced according to the procedure described by [4] [20]. The bags of Japanese millet seed (Echinochloa frumentaceae L.) with M. phaseolina cultures were incubated at $30^{\circ} \mathrm{C}$ for 3 wks., with periodic shaking to spread the inoculum within the bags. After 3 wks., of incubation at $30^{\circ} \mathrm{C}$, the millet was allowed to air dry and then stored in sealed plastic containers at $4^{\circ} \mathrm{C}$ until use. At planting, infested millet was applied in furrow with the seed at $1 \mathrm{~g}$ per $30.5 \mathrm{~cm}$ of row.

Even though infection of M. phaseolina may occur as early as V3 stage [4], the R7.2 and R7.8 are the critical stages when high level of disease severity occurs. The woody portion of the root and base of the stem may show black streaks when split, and this is the best diagnostic symptom where numerous small, black bodies of microsclerotia are visible. For two consecutive years, five plant samples were taken at random from each of the two outside rows of each plot. Sampling involved selecting plants at the phenological growth stage between R7.2 and R7.8 and cutting the stems off $10 \mathrm{~cm}$ above the soil. The soil was then loosened around the plants with a shovel, following that the plants and the mostly intact root systems were pulled from the soil. The 5-plant samples (each with the bottom $10 \mathrm{~cm}$ of stem and mostly intact root system) were placed in a nylon mesh bag (one 5-plant sample from the outside row of each plot). The plant samples were washed to remove any soil, air dried for 3 days, and then stored in a dehumidified cold room $\left(9^{\circ} \mathrm{C}, 18 \%\right.$ moisture $)$ until processing. Samples were obtained between 27 July and 13 August in 2012 and between 20 and 27 August in 2013.

The stem and root samples from each plot (two separate 5-plant samples from each plot) were first ground in a Thomas Model 4 Wiley Mill (Thomas Scientific, Swedesboro, NJ) fitted with a 2-mm mesh screen. A subsample was then passed through a Cyclotec 1093 Sample Mill (FOSS, Eden Prairie, MN) with a 1-mm mesh screen. Both mills were thoroughly cleaned between samples. The finely ground samples were then stored in sealed plastic vials at $4^{\circ} \mathrm{C}$ until analysis. An electronic blender (Waring Commercial, Torrington, CT) was employed to mix $0.005 \mathrm{~g}$ of ground tissue with $100 \mathrm{~mL}$ of $0.525 \% \mathrm{NaOCl}$ for $3 \mathrm{~min}$. The solution was passed through a $45-\mu \mathrm{m}$ pore size sieve. The triturate was washed with sterile distilled water and then added to $100 \mathrm{~mL}$ of autoclaved potato dextrose agar that had been cooled to $60^{\circ} \mathrm{C}$ and amended with rifampicin $\left(100 \mathrm{mg} \cdot \mathrm{L}^{-1}\right)$ and tergitol $(0.1 \mathrm{~mL})$ [4]. After 3 days of incubation at $30^{\circ} \mathrm{C}$, the colony forming units (CFU) of M. phaseolinawere counted and converted to CFU per gram stem and root tissue. The portion of the samples not used to identify the presence of charcoal rot disease was stored in a dehumidified chamber at $4^{\circ} \mathrm{C}$.

\subsection{Tissue Spectral Reflectance Measurements}

Spectral reflectance measurements of the ground tissue samples were obtained with a plant probe (PANalytical Boulder, Boulder, $\mathrm{CO}$ ) attached to the fiber optic cable of a full range hyperspectral spectroradiometer (Field Spec 3, PANalytical Boulder, Boulder, CO). The plant probe was equipped with a light source, allowing data collection at any time of day. The diameter of the spot size for the plant probe was $1 \mathrm{~cm}$. The spectroradiometer collects continuous spectral data in the range of 350 - $2500 \mathrm{~nm}$, has a sampling interval and spectral resolution of $1.4 \mathrm{~nm}$ and $3 \mathrm{~nm}$, respectively, in the $350 \mathrm{~nm}$ to $1000 \mathrm{~nm}$ spectral range, and has a spectral sampling interval and spectral resolution of $2 \mathrm{~nm}$ and $10 \mathrm{~nm}$, respectively, within the $1000 \mathrm{~nm}$ to $2500 \mathrm{~nm}$ spectral range. The final output of the wavelengths was resampled to $1 \mathrm{~nm}$ by the software used to operate the spectroradiometer.

A subsample of the finely ground stem and root tissue was transferred to $1.5 \mathrm{~cm}$ plastic petri dishes to accommodate the spot size (i.e. $1 \mathrm{~cm}$ ) of the plant probe. The 2012 and 2013 samples were removed from cold storage $48 \mathrm{~h}$ prior to collecting the spectral reflectance measurements. A spatula was employed to mix and to smooth the surface of the ground material in each petri dish. The plant probe was brought into direct contact with the surface of the ground plant material in the petri dish, and then the spectral reading an average of 15 
readings was recorded. The spectroradiometer was calibrated at $10 \mathrm{~min}$. intervals with a white spectralon panel (Spectralon Labsphere Inc., North Sutton, NH). Prior to spectral data collection, the spectroradiometer and the plant probe light source were warmed up for $2 \mathrm{~h}$ and for $30 \mathrm{~min}$., respectively. Compressed air and laboratory tissue were used to clean the spatula and the plant probe's lens between samples to prevent cross-contamination.

The $1 \mathrm{~nm}$ wavelengths were aggregated to $10 \mathrm{~nm}$ wavelengths to reduce the dimensionality of the dataset, reducing the number of spectral variables from 2151 to 214 for each sample. Wavelengths below $400 \mathrm{~nm}$ were also deleted because most artificial light sources produce wavelengths in the 400 - $2500 \mathrm{~nm}$ spectral range. The final number of spectral variables for each sample was 210 .

\subsection{Statistical Analyses}

Statistical analyses involved dividing the data acquired in each year into seven datasets: 1) Combined [i.e., dataset containing samples for all of the genotypes $(\mathrm{n}=120)], 2)$ "Clark" $(\mathrm{n}=20), 3)$ "LD00-3309" $(\mathrm{n}=20), 4)$ "LG03-4561-14" ( $\mathrm{n}=20), 5)$ "LG03-4561-19" ( $\mathrm{n}=20), 6)$ "Saline” $(\mathrm{n}=20)$, and 7) "Y227-1" $(\mathrm{n}=20)$. Hereafter, "LD00-3309", "LG03-4561-14", and "LG03-4561-19" are referred to as "LD00", "LG03-14”, and “LG03-19”, respectively.

Normality $(p<0.05)$ of the spectral variables and the microsclerotia content for each dataset was evaluated with box plots, histograms, quantile-quantile (QQ) plots, skew.2SE [i.e., skew divided by two times the standard error (absolute values greater than one are significant $(p<0.05)$ ], kurtosis.2SE [i.e., kurtosis divided by two times the standard error (absolute values greater than one are significant $(p<0.05)$ ], and the Wilk-Shapiro test [21]. The normality assumption requirements of Pearson correlation were not met for some variables. Therefore, the Spearman rank order correlation coefficient $\left(r_{s}\right)$ was employed to evaluate the strength of the relationship [22] between spectral reflectance properties and microsclerotia content of the plant tissue. It is a nonparametric test (i.e., does not rely on data being part of a distribution) that ranks the data for each variable and then applies Pearson's correlation equation to determine the associations between the ranked data [23]. Other researchers have used Spearman correlations to assess relationships between spectral reflectance data and plant components [24] [25]. The R software (version 3.0.2 [26]) was used to complete the statistical analysis. Box plots, histograms, and QQ plots; skew.2SE, kurtosis.2SE, and the Wilk-Shapiro test; and the correlation analysis were completed with ggplot2 [27], pastecs [28], and psych [29] packages, respectively, of the R software.

\section{Results}

A Spearman correlation analysis was conducted to evaluate relationships between spectral reflectance values and microsclerotia content of the stem and root tissue of six soybean genotypes. The analysis consisted of spectral reflectance measurements of diseased and non-diseased stem and root tissue for each genotype. Statistically significant $(p<0.05)$ correlations were observed between spectral reflectance values and microsclerotia content in the visible (400 - $670 \mathrm{~nm})$, red-edge $(680$ - $760 \mathrm{~nm})$, near-infrared $(770$ - $1290 \mathrm{~nm})$, and shortwave-infrared (1300 - $2490 \mathrm{~nm}$ ) regions of the light spectrum (Figure 1, Figure 2). These relationships were genotype dependent. Overall, visible, red-edge, and near-infrared reflectance values had negative correlations with microsclerotia content in the soybean plant tissue (Figure 1, Figure 2). Typically, positive relationships were noted between shortwave-infrared reflectance values and microsclerotia content (Figure 1, Figure 2). The only exclusions were the negative correlation observed between shortwave-infrared reflectance values and microsclerotia content of the Clark and LD00 samples obtained in 2012 and 2013, respectively. Similar correlation patterns existed across years for the combined dataset and the Clark, the LG03-19, and the Saline dataset. Even though the patterns were similar, the best correlations were year dependent.

Statistically significant $(p<0.05)$ correlation coefficients with the greatest association between tissue spectral reflectance values and microsclerotia content are presented in Table 1 . Reflectance values of near-infrared wavelengths had the strongest relationships with microsclerotia content for the Combined, LD00, LG03-14, LG0319, Saline, and Y227-1 2012 datasets and for the Combined, Clark, and Saline 2013 datasets. Wavelengths within the shortwave-infrared region of the spectrum were ranked best for the LG03-14 and the LG03-19 2013 datasets. A tie occurred between top ranked near-infrared and shortwave-infrared wavelengths reflectance values for the Clark 2012 dataset. None of the spectral data exhibited statistically significant relationships $(p<0.05)$ with microsclerotia content for the LD00 and Y227-1 genotypes datasets in 2013. 


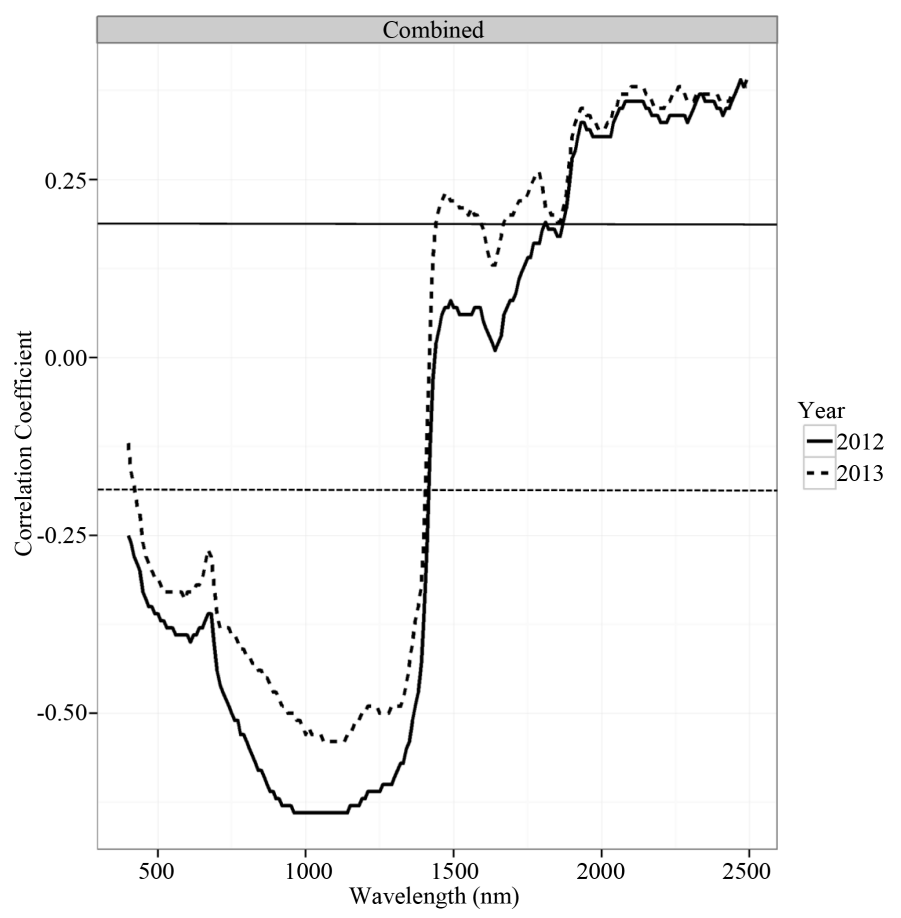

Figure 1. Plot showing Spearman correlation coefficients between reflectance values per wavelength and microsclerotia content of soybean stem/root tissue for the combined genotype dataset $(n=120)$. Statistically significant correlation coefficients $(p<0.05)$ are located above the horizontal solid black line and below the horizontal black dashed line in the figure. Spectral regions: visible $(400-670 \mathrm{~nm})$, red-edge $(680-760 \mathrm{~nm})$, near-infrared $(770-1290 \mathrm{~nm})$, and shortwave-infrared $(1300-2490 \mathrm{~nm})$.

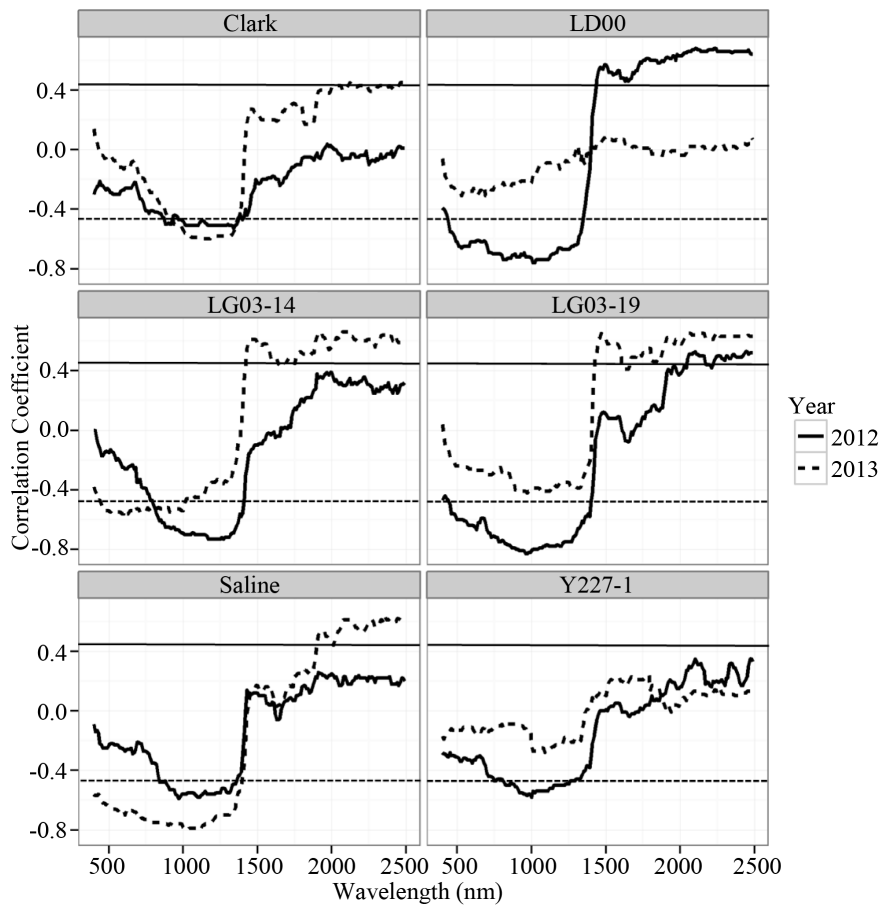

Figure 2. Plots showing Spearman correlation coefficients between reflectance values per wavelength and microsclerotia content of soybean stem/root tissue for each genotype $(\mathrm{n}=20)$. Statistically significant correlation coefficients $(p<0.05)$ are located above the horizontal solid black lines and below the horizontal dashed black lines in the figure. Spectral regions: visible (400 - $670 \mathrm{~nm})$, red-edge $(680-760 \mathrm{~nm})$, near-infrared $(770-1290 \mathrm{~nm})$, and shortwave-infrared $(1300-2490 \mathrm{~nm})$. 
Table 1. Top ranked Spearman correlation coefficients of reflectance values per wavelength versus microsclerotia content in soybean plant tissue.

\begin{tabular}{|c|c|c|c|c|}
\hline Dataset & Year & Wavelengths (nm) & Spectral region & Correlation coefficient \\
\hline \multirow[t]{2}{*}{ Combined $^{\mathrm{a}}$} & 2012 & $960-1140$ & Near-infrared & $r_{\mathrm{s}}=-0.64, p<0.05, \mathrm{n}=120$ \\
\hline & 2013 & $1060-1130$ & Near-infrared & $r_{s}=-0.54, p<0.05, \mathrm{n}=120$ \\
\hline \multirow[t]{2}{*}{ Clark } & 2012 & $\begin{array}{c}1020-1100,1170-1290 \\
1310-1330,1350\end{array}$ & $\begin{array}{c}\text { Near-infrared } \\
\text { Shortwave-infrared }\end{array}$ & $r_{s}=-0.51, p<0.05, \mathrm{n}=20$ \\
\hline & 2013 & $1110-1180$ & Near-infrared & $r_{s}=-0.60, p<0.05, \mathrm{n}=20$ \\
\hline \multirow[t]{2}{*}{ LD00 } & 2012 & 1010,1020 & Near-infrared & $r_{\mathrm{s}}=-0.76, p<0.05, \mathrm{n}=20$ \\
\hline & 2013 & & & $\mathrm{NS}^{\mathrm{b}}$ \\
\hline \multirow[t]{2}{*}{ LG03-14 } & 2012 & $1170-1250,1270$ & Near-infrared & $r_{s}=-0.73, p<0.05, \mathrm{n}=20$ \\
\hline & 2013 & 1920, 1930, $2070-2120$ & Shortwave-infrared & $r_{s}=0.66, p<0.05, \mathrm{n}=20$ \\
\hline \multirow[t]{2}{*}{ LG03-19 } & 2012 & 960,970 & Near-infrared & $r_{s}=-0.83, p<0.05, \mathrm{n}=20$ \\
\hline & 2013 & 2250 & Shortwave-infrared & $r_{s}=0.66, p<0.05, \mathrm{n}=20$ \\
\hline \multirow[t]{2}{*}{ Saline } & 2012 & 970 & Near-infrared & $r_{s}=-0.59, p<0.05, \mathrm{n}=20$ \\
\hline & 2013 & 1030, 1100, 1110 & Near-infrared & $r_{s}=-0.80, p<0.05, \mathrm{n}=20$ \\
\hline \multirow[t]{2}{*}{ Y227-1 } & 2012 & 1000 & Near-infrared & $r_{s}=-0.58, p<0.05, \mathrm{n}=20$ \\
\hline & 2013 & & & NS \\
\hline
\end{tabular}

${ }^{\mathrm{a}}$ Data of all genotypes were evaluated together. ${ }^{\mathrm{b}} \mathrm{NS}=$ no significant correlations at $p<0.05$.

\section{Discussion}

This study evaluated the relationships between spectral reflectance properties and microsclerotia content in soybean stem-root tissue samples. Moderate $\left(r_{s}= \pm 0.40\right.$ to \pm 0.59$)$, strong $\left(r_{s}= \pm 0.60\right.$ to \pm 0.79$)$, and very strong $\left(r_{s}= \pm 0.80\right.$ to \pm 1.00 ) negative and positive monotonic relationships [30] were observed between tissue spectral reflectance values and tissue microsclerotia content (Figure 1, Figure 2). Reflectance values obtained in the near-infrared and shortwave-infrared regions of the light spectrum had the best relationships with microsclerotia content (Table 1), with the best relationship occurring most often with near-infrared wavelengths' reflectance values.

Near-infrared and shortwave-infrared wavelengths have proven to be useful predictors of the chemical composition of ground and solid wood products, including lignin, cellulose, hemicellulose, glucose, xylose, acetyl, and other components [31] [32]. References [31] and [32] obtained correlation values greater than 0.80 for models employing near-infrared and shortwave-infrared wavelengths to predict the wood chemical compounds. To put our study into perspective, we used Spearman correlation and not models to assess the relationships, and we evaluated a combination of root and stem tissues. Nevertheless, one could speculate that changes in the chemical structure of the soybean stem such as lignin, cellulose, hemicellulose, glucose, xylose, acetyl, etc., were related to changes in microsclerotia content. Reference [33] indicated that resistance to stem rot of soybeans [Sclerotinia sclerotiorum (Lib.) de Bary] was associated with low stem lignin concentration and that soybean stem lignin concentration can be used as a biological marker to select for resistance to S. sclerotiorum. Future research on microsclerotia content should address the relationship between lignin and charcoal rot severity.

The combined dataset statistically significant relationships $(p<0.05)$ were important because it consisted of a diverse group of soybean genotypes, provided a wide range of microsclerotia content and spectral reflectance values, and identified wavelengths to employ across genotypes. Between years an overlap occurred for the best correlation coefficients for the combined dataset at 1060 to $1130 \mathrm{~nm}$ (Table 1), the near-infrared region of the light spectrum. The reflectance values of the wavelengths within the 1060 to 1130 range were not ranked the overall best for the individual genotype datasets (Table 1). Nevertheless, those wavelengths reflectance values were statistically significantly correlated with the microsclerotia content for nine out of twelve of the genotype datasets (Figure 2). Spectral wavelengths in the near-infrared region of the light spectrum have potential as a tool to assess variation in microsclerotia content and density in soybean stem and root tissue. Decreases in nearinfrared reflectance values were associated with increases in microsclerotia content in the stem and root tissue of 
soybean plants, and this correlation may have implications in the level of resistance in the genotypes tested.

\section{Conclusion}

The results of this study provided evidence that relationships exist between soybean stem and root tissue spectral reflectance and the microsclerotia content of that tissue, supporting spectral reflectance data as a means for assessing charcoal rot disease in soybean plants. The near-infrared region of the light spectrum provided the best avenue to assess microsclerotia density. Future research should focus on the modelling capabilities of the selected wavelengths and on the feasibility of using the selected wavelengths in machine learning algorithms to differentiate non-diseased from diseased susceptible soybean plant tissue.

\section{Acknowledgements}

The authors thank Milton Gaston Jr. for his assistance in this study. This work was supported by United States Department of Agriculture, Agricultural Research Service (USDA, ARS) project numbers 6402-22000-079-00D, 6402-21220-010-00D, and 6645-21000-0-00D. Mention of trade names or commercial products in this publication is solely for the purpose of providing specific information and does not imply recommendation or endorsement by the United States Department of Agriculture.

\section{References}

[1] Wrather, J.A. and Koenning, S.R. (2009) Effects of Diseases on Soybean Yields in the United States 1996 to 2007. Plant Health Progress. http://dx.doi.org/10.1094/PHP-2009-0401-01-RS

[2] Westphal, A., Abney, T.S. and Shaner, G. (2006) Diseases of Soybean: Charcoal Rot. Purdue Extension, BP-42-W. https://www.extension.purdue.edu/extmedia/BP/BP-42-W.pdf

[3] Bissonnette, S. (2012) Charcoal Rot Is a Hot Disease in Soybeans. http://agfax.com/2012/08/13/Illinois-charcoal-rot-a-hot-disease-in-soybeans/

[4] Mengistu, A., Ray, J.D., Smith, J.R. and Paris, R.L. (2007) Charcoal Rot Disease Assessment of Soybean Genotypes using a Colony Forming Unit Index. Crop Science, 47, 2453-2461. http://dx.doi.org/10.2135/cropsci2007.04.0186

[5] Smith, G.S. and Wyllie, T.D. (1999) Charcoal Rot. In: Hartman, G.L., Sinclair, J.B. and Rupe, J.C., Eds., Compendium of Soybean Diseases, 4th Edition, American Phytopathological Society, St. Paul, 29-31.

[6] Odvody, G.N. and Dunkle, L.D. (1979) Charcoal Stalk Rot of Sorghum: Effect of Environment on Host-Parasite Relations. Phytopathology, 69, 250-254. http://dx.doi.org/10.1094/Phyto-69-250

[7] Paris, R.L., Mengistu, A., Tyler, J.M. and Smith, J.R. (2006) Registration of Soybean Germplasm Line DT97-4290 with Moderate Resistance to Charcoal Rot. Crop Science, 46, 2324-2325. http://dx.doi.org/10.2135/cropsci2005.09.0297

[8] Sarr, M.P., Ndiaye, M., Groenewald, J.Z. and Crous, P.W. (2014) Genetic Diversity in Macrophomina phaseolina, the Causal Agent of Charcoal Rot. Phytopathologia Mediterranea, 53, 250-268.

[9] Smith, G.S. and Carvil, O.N. (1997) Field Screening of Commercial and Experimental Soybean Cultivars for Their Reaction to Macrophomina phaseolina. Plant Disease, 81, 363-368. http://dx.doi.org/10.1094/PDIS.1997.81.4.363

[10] Delalieux, S., van Aardt, J., Keulemans, W. and Coppin, P. (2007) Detection of Biotic Stress (Venturia inaequalis) in Apple Trees using Hyperspectral Data: Nonparametric Statistical Approaches and Physiological Implications. European Journal of Agronomy, 27, 130-143. http://dx.doi.org/10.1016/j.eja.2007.02.005

[11] Mahlein, A.K., Steiner, U., Dehne H.W. and Oerke, E.C. (2010) Spectral Signatures of Sugar Beet Leaves for the Detection and Differentiation of Diseases. Precision Agriculture, 11, 413-431. http://dx.doi.org/10.1007/s11119-010-9180-7

[12] Mahlein, A.K., Steiner, U., Hillnhütter, C., Dehne, H.W. and Oerke E.C. (2012) Hyperspectral Imaging for SmallScale Analysis of Symptoms Caused by Different Sugar Beet Diseases. Plant Methods, 8, 3. http://dx.doi.org/10.1186/1746-4811-8-3

[13] Ray, S.S., Jain, N., Arora, R.K., Chavan, S. and Panigrahy, S. (2011) Utility of Hyperspectral Data for Potato Late Blight Disease Detection. Journal of the Indian Society of Remote Sensing, 39, 161-169. http://dx.doi.org/10.1007/s12524-011-0094-2

[14] Rumpf, T., Mahlein, A.K., Steiner, U., Oerke, E.C., Dehne, H.W. and Plümer, L. (2010) Early Detection and Classification of Plant Diseases with Support Vector Machines Based on Hyperspectral Reflectance. Computers and Electronics in Agriculture, 74, 91-99. http://dx.doi.org/10.1016/j.compag.2010.06.009 
[15] Sankaran, S., Mishra, A., Ehsani, R. and Davis, C. (2010) A Review of Advanced Techniques for Detecting Plant Diseases. Computers and Electronics in Agriculture, 72, 1-13. http://dx.doi.org/10.1016/j.compag.2010.02.007

[16] Naidu, R.A., Perry, E.M., Pierceb, F.J. and Mekuria, T. (2009) The Potential of Spectral Reflectance Technique for the Detection of Grapevine Leafroll-Associated Virus-3 in Two Red-Berried Wine Grape Cultivars. Computers and Electronics in Agriculture, 66, 38-45. http://dx.doi.org/10.1016/j.compag.2008.11.007

[17] Johnson, H.W. (1958) Registration of Soybean Varieties, VI. Agronomy Journal, 50, 690-691. http://dx.doi.org/10.2134/agronj1958.00021962005000110016x

[18] Owen, P.A., Nickell, C.D., Noel, G.R., Thomas, D.J. and Frey, K. (1994) Registration of 'Saline’ Soybean. Crop Science, 34, 1689. http://dx.doi.org/10.2135/cropsci1994.0011183X003400060051x

[19] Diers, B.W., Cary, T.R., Thomas, D.J. and Nickell, C.D. (2006) Registration of "LD00-3309” Soybean. Crop Science, 46, 1384. http://dx.doi.org/10.2135/cropsci2005.06.0164

[20] Mengistu, A., Ray, J.D., Smith, J.R. and Boykin, D.L. (2014) Maturity Effects on Colony-Forming Units of Macrophomina phaseolina Infection as Measured Using Near-Isogenic Lines of Soybeans. Journal of Crop Improvement, 28, 38-56. http://dx.doi.org/10.1080/15427528.2013.858284

[21] Field, A., Miles, J. and Field, Z. (2012) Discovering Statistics Using R. Sage Publication Ltd., London.

[22] Sheskin, D.J. (2007) Spearman's Rank-Order Correlation Coefficient. In: Sheskin, D.J., Ed., Handbook of Parametric and Nonparametric Statistical Procedures, 4th Edition, Chapman \& Hall/CRC, Boca Raton, 1353-1370.

[23] McKillup, S. (2005) Statistics Explained an Introductory Guide for Life Scientists. Cambridge University Press, Cambridge. http://dx.doi.org/10.1017/CBO9780511815935

[24] Bálint, J., Balázs, V.N. and Fail, J. (2013) Correlations between Colonization of Onion Thrips and Leaf Reflectance Measures across Six Cabbage Varieties. PLoS ONE, 8, e73848. http://dx.doi.org/10.1371/journal.pone.0073848

[25] Stein, B.R., Thomas, V.A., Lorentz, L.J. and Strahm, B.D. (2014) Predicting Macronutrient Concentrations from Loblolly Pine Leaf Reflectance across Local and Regional Scales. GI Science and Remote Sensing, 51, 269-287.

[26] R Core Team (2013) R: A Language and Environment for Statistical Computing. R Foundation for Statistical Computing, Vienna. http://www.R-project.org/

[27] Wickham, H. (2009) GGplot2: Elegant Graphics for Data Analysis. Springer, New York. http://dx.doi.org/10.1007/978 -0-387-98141-3

[28] Grosjean, P. and Ibanez, F. (2014) Pastecs: Package for Analysis of Space-Time Ecological Series. R Package Version 1.3-18. http://CRAN.R-project.org/package=pastecs

[29] Revelle, W. (2013) Psych: Procedures for Personality and Psychological Research. Northwestern University, Evanston. http://CRAN.R-project.org/package=psych

[30] Evans, J.D. (1996) Straightforward Statistics for the Behavioral Sciences. Brooks/Cole Publishing, Pacific Grove.

[31] Schimleck, L., Wright, P., Michell, A. and Wallis, A. (1997) Near Infrared Spectra and Chemical Compositions of E. globules and E. nitens Plantation Woods. Appita Journal, 50, 40-46.

[32] Kelley, S.S., Rials, T.G., Snell, R., Groom, L.H. and Sluiter, A. (2004) Use of Near Infrared Spectroscopy to Measure the Chemical and Mechanical Properties of Solid Wood. Wood Science Technology, 38, 257-276. http://dx.doi.org/10.1007/s00226-003-0213-5

[33] Peltier, A.J., Hatfield, R.D. and Grau, C.R. (2009) Soybean Stem Lignin Concentration Relates to Resistance to Sclerotinia sclerotiorum. Plant Disease, 93, 149-154. http://dx.doi.org/10.1094/PDIS-93-2-0149 
Scientific Research Publishing (SCIRP) is one of the largest Open Access journal publishers. It is currently publishing more than 200 open access, online, peer-reviewed journals covering a wide range of academic disciplines. SCIRP serves the worldwide academic communities and contributes to the progress and application of science with its publication.

Other selected journals from SCIRP are listed as below. Submit your manuscript to us via either submit@scirp.org or Online Submission Portal.
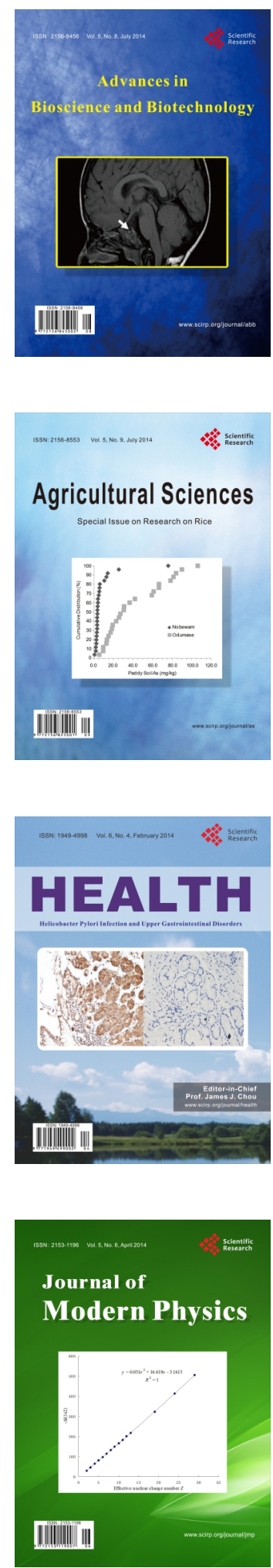
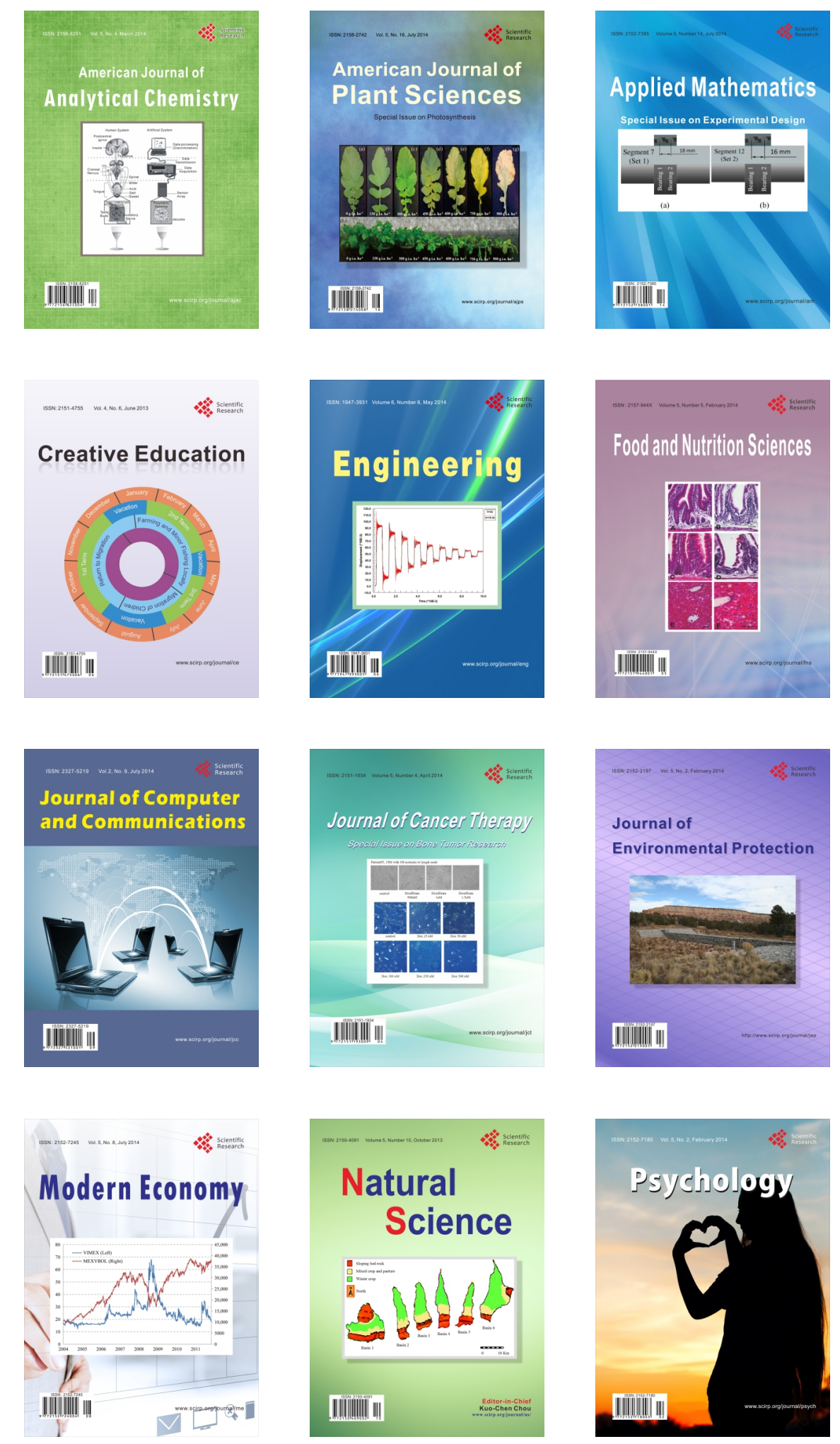